\title{
Spermiogenesis and spermatozoa ultrastructure in five species of the Curimatidae with some considerations on spermatozoal ultrastructure in the Characiformes
}

\author{
Irani Quagio-Grassiotto*, Maria Carolina Gameiro*, Tatiana Schneider*, \\ Luiz Roberto Malabarba** and Claudio Oliveira*
}

\begin{abstract}
Spermiogenesis in the curimatid species, Steindachnerina insculpta, Cyphocharax gillii, C. modestus, C. spilotus, and Potamorhina altamazonica, is characterized by lateral development of the flagellum, nuclear rotation, eccentric nuclear fossa formation, and chromatin compacted into thick fibers. These spermatozoa exhibit a spherical head containing a nucleus with the chromatin highly condensed into thick fibers with small electron-lucent areas, and no acrosome. The nuclear fossa is of the moderate type and eccentric and penetrated by the centriolar complex. The midpiece is small, has many elongate vesicles, and a short cytoplasmic channel. Mitochondria may be elongate, branched or $\mathrm{C}$-shaped, and are separated from the initial segment of the axoneme by the cytoplasmic channel. The flagellum contains the classical axoneme structure $(9+2)$ and has a membranous compartment in the initial region; it does not have lateral fins. Only small differences were observed among the analyzed species and genera of the Curimatidae. Spermiogenesis and spermatozoa in the Curimatidae have many of the characteristics found in almost all other characiform species. On the other hand, the presence of a membranous compartment in the initial region of curimatid flagella, a structure common in many Cypriniformes spermatozoa, is unknown in other characiforms. Spermiogenesis and the spermatozoa of the Characiformes are discussed.
\end{abstract}

A espermiogênese nas espécies Steindachnerina insculpta, Cyphocharax gillii, C. modestus, C. spilotus e Potamorhina altamazonica de Curimatidae é caracterizada pelo desenvolvimento lateral do flagelo, rotação do núcleo, formação excêntrica da fossa nuclear e cromatina compactada em fibras espessas. Estes espermatozóides exibem uma cabeça esférica contendo um núcleo com cromatina altamente condensada em fibras espessas com pequenas áreas eletronlúcidas, e sem acrossoma. A fossa nuclear é do tipo moderado e excêntrico, penetrada pelo complexo centriolar. A peça média é pequena, tem muitas vesículas alongadas e um curto canal citoplasmático. Mitocôndrias podem ser alongadas, ramificadas ou em forma de C, e são separadas do segmento inicial do axonema pelo canal citoplasmático. O flagelo contém a estrutura clássica do axonema (9+2) e tem um compartimento membranoso na região inicial; não possui expansões laterais ("fins"). Somente pequenas diferenças foram observadas entre as espécies e gêneros analisados de Curimatidae. A espermiogênese e os espermatozóides de Curimatidae têm muitas das características encontradas em quase todas as outras espécies de Characiformes. Por outro lado, a presença de um compartimento membranoso na região inicial do flagelo dos curimatídeos, uma estrutura comum nos espermatozóides de muitos cipriniformes, é desconhecida em outros characiformes. Discute-se sobre a espermiogênese e espermatozóides de Characiformes.

Key Words: fish, spermatid, sperm, ultrastructure.

\section{Introduction}

Studies conducted on several fish species have shown that processes of spermiogenesis, as well as spermatozoal types and structures, are usually conserved among the members of a given family (Mattei, 1991; Jamieson, 1991).
Therefore, the characterization of such attributes may be useful in the identification of the patterns of relationship found among families. Although the studies by Jamieson (1991) and Mattei $(1988,1991)$ provided data on spermatozoon structure in the majority of the most important fish groups of the World, the spermatozoa of relatively few Neotropical freshwater fishes

\footnotetext{
* Departamento de Morfologia, Instituto de Biociências, Universidade Estadual Paulista, 18618-000 Botucatu, SP, Brazil. e-mail (IQG): morfologia@ibb.unesp.br

** Departamento de Zoologia, IB, Universidade Federal do Rio Grande do Sul, Av. Bento Gonçalves, 9500, bloco IV, Prédio 43435, 90540-000 Porto Alegre, RS, Brazil; and Museu de Ciêncìas e Tecnologia, PUCRS, Av. Ipiranga 6681, 90619-900, Porto Alegre, RS, Brazil
} 
have been described (Quagio-Grassiotto and Carvalho, 2000; Quagio-Grassiotto et al., 2001).

The Characiformes is one of the dominant groups in Neotropical freshwaters. Buckup (1998) divided Characiformes into two sub-orders: Citharinoidei, divided into two families; and Characoidei, divided into 8 super-families and 18 families. The families Distichodontidae and Citharinidae that jointly constitute the Citharinoidei, and the Hepsetidae and Alestidae that are components of the Characoidei, are endemic to Africa while the remaining families are distributed throughout Central and South America. Based on the number of recently described taxa in the Neotropical ichthyofauna, Vari (1998) estimates that the number of species of the Characiformes in Central and South America may exceed 2000. As a consequence of the large number of species and their wide distribution, the relationships among many groups of Characiformes remain unresolved (Buckup, 1998).

The family Curimatidae has about 100 species widely distributed throughout the freshwaters of South and Central America (Vari, 1989). Vari (1983), based on a series of osteological and anatomical characters, presented a phylogeny in which Curimatidae, along with Prochilodontidae, Anostomidae and Chilodontidae, comprise a monophyletic assemblage, the superfamily Anostomoidea by Buckup (1998). The Curimatidae is considered to be a sister group to Prochilodontidae and these two families, in turn, are considered to be sister groups to the monophyletic lineage formed by the Anostomidae and Chilodontidae (Vari, 1983).

In light of the limited available information on either spermiogenesis or spermatozoal structure in Neotropical characiforms, the present study describes these characters in five species of three genera of the Curimatidae (Cyphocharax, Potamorhina, and Steindachnerina) and compares those observations with the data available on Curimata inornata (Matos et al., 1998). We also discuss spermiogenesis and the spermatozoal ultrastructure in the Characiformes.

\section{Materials and Methods}

Adult males of Cyphocharax modestus (5 specimens LBP75) and Steindachnerina insculpta (5 specimens LBP63) were collected from the Jurumirim Reservoir, rio Paranapanema, São Paulo, Brazil (2331'10” S; 4842’35” W); Cyphocharax gillii (1 specimen - LBP660) was collected in a tributary of the rio Piraí, Poconé, Mato Grosso, Brazil (16²5.680' S; 56²5.143' W); Cyphocharax spilotus (1 specimen - UFRGS 5926) was collected from the rio Vacacaí, São Gabriel, Rio Grande do Sul, Brazil (30²1'34"S; $54^{\circ} 18^{\prime} 48^{\prime \prime} \mathrm{W}$ ); and Potamorhina altamazonica (5 specimens - LBP1550) was collected from the rio Acre, Rio Branco, Acre, Brazil $\left(10^{\circ} 03.320^{\prime} \mathrm{S} ; 6^{\circ} 51.450^{\prime} \mathrm{W}\right)$. The voucher specimens of C. modestus, S. insculpta, C. gillii and P. altamazonica are kept at the collection of Laboratório de Biologia de Peixes (LBP), Departamento de Morfologia, Universidade Estadual Paulista, and those of $C$. spilotus at the collection of the Departamento de Zoologia, Universidade Federal do Rio Grande do Sul (UFRGS).

Gonad fragments from newly sacrificed fishes were fixed overnight in $2 \%$ glutaraldehyde and $4 \%$ paraformaldehyde in $0.1 \mathrm{M}$ Sorensen phosphate buffer, $\mathrm{pH}$ 7.4. The material was post-fixed in the dark for 2 hours in $1 \%$ osmium tetroxide in the same buffer, stained with a 5\% aqueous solution of uranyl acetate for two hours, dehydrated in acetone, embedded in araldite, and sectioned and stained with a saturated solution of uranyl acetate in 50\% alcohol and lead citrate. Electromicrographs were obtained using a Phillips CM 100 transmission electron microscope.

\section{Results}

Spermiogenesis in the Curimatidae. In the analyzed curimatid species, as in teleost fishes in general, spermiogenesis occurs in cysts in the germinative epithelium. These cysts consist of a group of germ cells at the same developmental stage and are surrounded by cytoplasmic processes of Sertoli cells. In the cysts, the early spermatids are interconnected by cytoplasmic bridges that result from incomplete cytokinesis during mitotic and meiotic divisions.

In the early spermatids, the cytoplasm symmetrically encircles the nucleus, which shows diffuse chromatin and has a circular outline (Fig. 1a). The centriolar complex lies lateral to the nucleus and anchors to the plasma membrane, forming the flagellum (Fig. 1a). The centriolar complex, with the proximal centriole anterior and slightly oblique to the distal centriole (Fig. 1b, 1d, 1e, 1g, 1h, and 1k), moves towards the nucleus, bringing with it the plasma membrane and the initial segment of the flagellum, that invaginates (Fig. 1a, 1b and $1 \mathrm{~g}$ ).

The cytoplasmic channel, a space between the plasma membranes of the flagellar region and the main part of the cell, is then formed (Fig. 1b, 1f, 1g, 1n and 1p). The flagellum has a classical $9+2$ axoneme with nine peripheral microtubular doublets and a single pair of central microtubules, surrounded by the flagellar membrane (Fig. 1b and 1q). The mitochondria are rounded to elongate, with abundant cristae and an electron-dense matrix (Fig. 1a, 1b, 1e - 1h, 1j, 11 - 1n, and 1o). The endomembrane system has numerous cisternae or vesicles (Fig. 1f and 1n).

When the nucleus starts to rotate, a depression is formed in the nuclear outline at the level of the centriolar complex, and this gives rise to the nuclear fossa (Fig. 1j, 1o, and 1p). The distal centriole, that is anchored by radial fibrils and differentiated into the basal body, remains associated with the plasma membrane (Fig. 1b and 1c). Chromatin condensation occurs during the time of nuclear rotation, with areas of diffuse chromatin seen among areas of condensing chromatin in the nucleus (Fig. 1g - 1j). The centriolar complex penetrates into the nuclear fossa. The nuclear fossa is relatively shallow and slightly eccentrically positioned (Fig. $1 \mathrm{~h}$ and $1 \mathrm{p}$ ). Consequently, the centriolar complex is also eccentric (Fig.1h and 1p). 

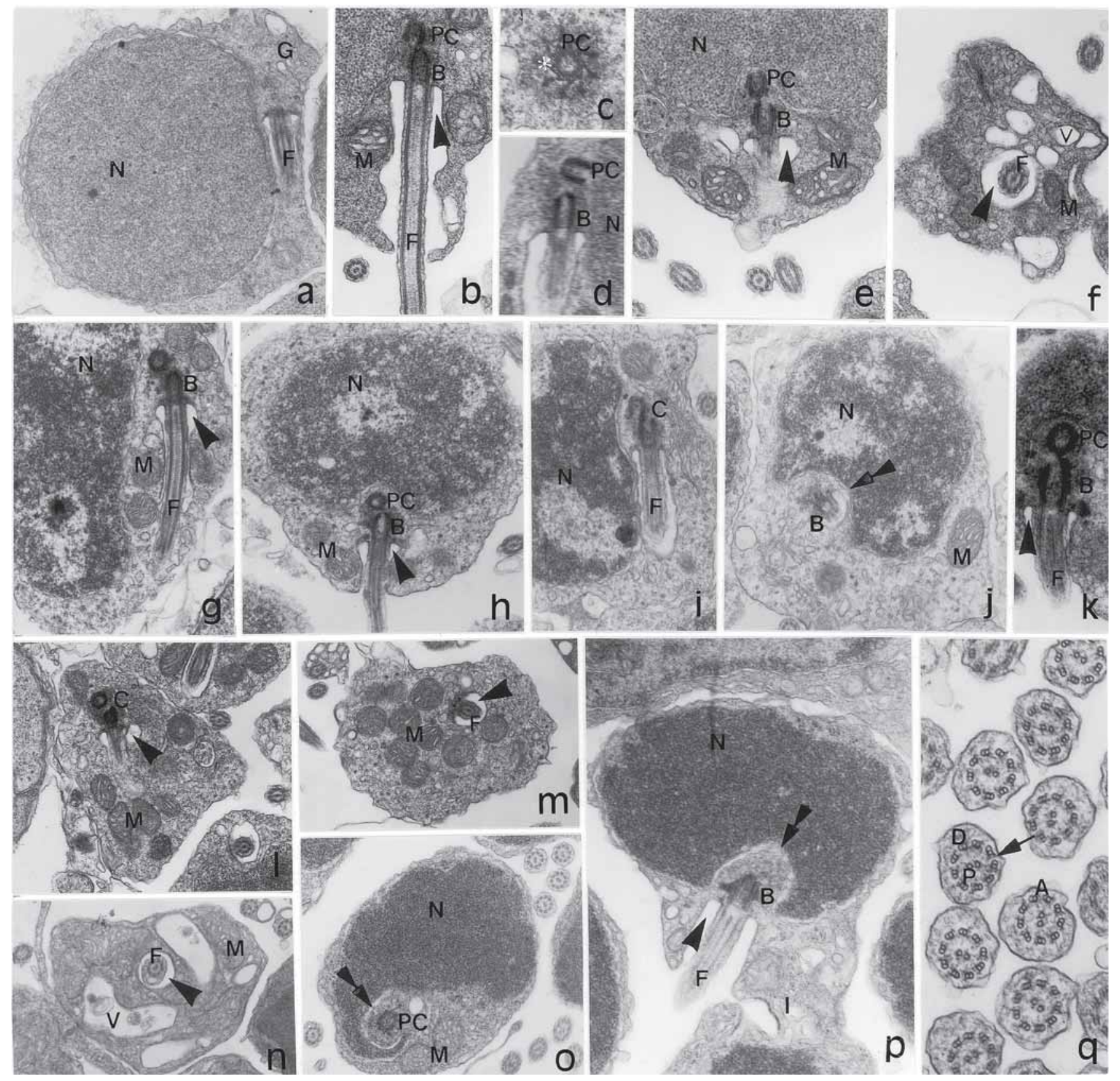

Fig. 1: Cyphocharax modestus (a and $\mathbf{d})$, Potamorhina altamazonica $(\mathbf{c}, \mathbf{g}, \mathbf{h}, \mathbf{m}$, and $\mathbf{n})$ and Steindachnerina insculpta (b, e, $\mathbf{f}, \mathbf{i}, \mathbf{j}, \mathbf{k}, \mathbf{l}, \mathbf{o}, \mathbf{p}$, and $\mathbf{q}$ ) spermatids. a - f: early spermatids; a: longitudinal section, X 13200; $\mathbf{b}$ and e: midpiece longitudinal sections; b, X 17000; e, X 18400; c: centriole anchorage, X 31500; d: centriolar complex, X 17000; f: midpiece cross section, X 18400; g - m: spermatids; $\mathbf{g}$-j: longitudinal sections; $\mathbf{g}$, X 13600; h - j, X 13200; k: centriolar complex, X 17000; I and m: midpiece cross sections, X 11900; $\mathbf{n}$ - q: late spermatids; $\mathbf{n}$ and $\mathbf{o}$ : midpiece cross sections; $\mathbf{n}, \mathrm{X}$ 13600; o, X 14700; $\mathbf{p}$ : spermatid longitudinal section, X 13200; q, flagella cross sections, X 42000. A: axoneme; B: basal body; C: centriolar complex; D: peripheral microtubule doublets; F: flagellum; G: Golgi complex; I: intercellular bridges; M: mitochondrion; MP: midpiece; N: nucleus; P: single central pair of microtubules; PC: proximal centriole; V: vesicle; arrow: dinein arm; arrowhead: cytoplasmic channel; double arrowhead: nuclear fossa; white asterisks: anchorage fibrils.

The cytoplasmic mass moves around the initial segment of the tail and gives rise to the midpiece of the future spermatozoon (Fig. 1b, 1f, 11, 1m, and 1n).

In the final spermatids, the nucleus contains highly condensed, thin fibers of chromatin (Fig. 1o and 1p). The basal body remains anchored to the plasma membrane and the mitochondria are separated from the initial segment of the flagellum by the cytoplasmic channel (Fig. $1 \mathrm{~m}$ and 1p).

At the end of spermiogenesis, residual cytoplasm and intercellular bridges are eliminated. The cytoplasmic proces- 
ses of Sertoli cells move away, releasing spermatozoa into the lumen of the seminiferous compartment.

Spermatozoa of the Curimatidae. Curimatid spermatozoa have a head, a midpiece and a tail or flagellum. The head exhibits no acrosomal vesicle. It contains a spherical nucleus, $1.8 \mu \mathrm{m}$ in diameter, surrounded by a narrow strip of cytoplasm with no organelles. The nuclear outline shows a moderate and slightly eccentric depression, the nuclear fossa. The nucleus is occupied by thin fibers of highly condensed chromatin (Figs. 2-6).

The centriolar complex penetrates into the nuclear fossa
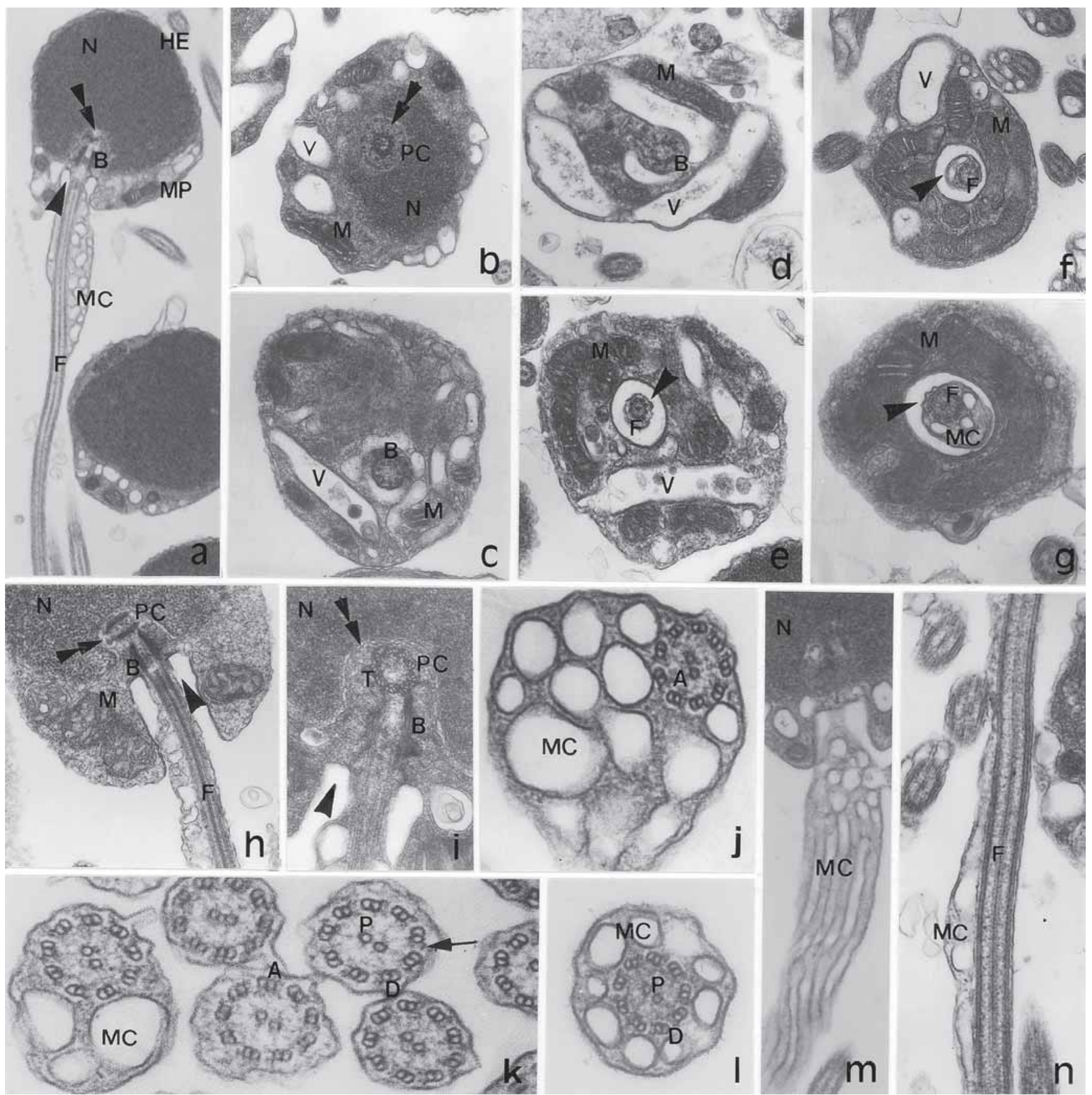

Fig. 2. Cyphocharax modestus spermatozoa. a: spermatozoon longitudinal section, X 13000; b - g: midpiece cross sections; b, X 18000; c, X19300; d-f, X 22000; g, X 33700; h: midpiece longitudinal section, X 21000; i: centriolar complex, X 40000; j-l: flagella cross sections; $\mathbf{j}$ and $\mathbf{k}, \mathrm{X}$ 80000; $\mathbf{l}, \mathrm{X}$ 69000; $\mathbf{m}$ and $\mathbf{n}$ : flagella longitudinal sections; $\mathbf{m}, \mathrm{X} 23000 ; \mathbf{n}, \mathrm{X} 31500$. A: axoneme; B: basal body; C: centriolar complex; D: peripheral microtubular doublets; F: flagellum; HE: head; M: mitochondria; MC: membranous compartment; MP: midpiece; N: nucleus; P: single central pair of microtubules; PC: proximal centriole; V: vesicle; arrow: dinein arm; arrowhead: cytoplasmic channel; double arrowhead: nuclear fossa. 
and is surrounded by a thin layer of electron-dense material (Fig. 2h and 2i; Fig. 3b; Fig. 4b; Fig. 5b; Fig. 6b). In the analyzed species, the proximal centriole is anterior, medial to slightly lateral, and at a right or slightly oblique angle to the distal centriole (Fig. 2h and 1i; Fig. 3b; Fig. 4a and 4b; Fig. 5b and 5f; Fig. 6b).

In the midpiece, there are many elongate vesicles and large, elongate, $\mathrm{C}$-shaped or ramified mitochondria, some are close to the nucleus and separated from the flagella by the cytoplasmic channel (Fig. 2b-2h; Fig. 3c - 3f; Fig. 4b - 4f and 4h; Fig. 5c-5f; Fig. 6b-6h).

The flagellum is eccentric and shows in its basal region a membranous compartment formed by antero-posteriorly elongate vesicles interspersed with a narrow strip of cytoplasm (Fig. 2a, $2 \mathrm{~h}$ and $2 \mathrm{j}-2 \mathrm{~m}$; Fig. $3 \mathrm{~g}$ and $3 \mathrm{~h}$; Fig. $4 \mathrm{~g}$ and $4 \mathrm{i}$; Fig. $5 \mathrm{a}$ and $5 \mathrm{~h}-5 \mathrm{j}$; Fig. $6 a$ and $6 j-61)$. The axoneme is lateral to the membranous compartment in species of Cyphocharax and Potamorhina altamazonica (Fig. 2a, $2 \mathrm{~h}$ and $2 \mathrm{j}-2 \mathrm{~m}$; Fig. $3 \mathrm{~g}$ and $3 \mathrm{~h}$; Fig. $4 \mathrm{~g}$ and 4i; Fig. 5a and 5h-5j), and medial in Steindachnerina insculpta (Fig. 6a and $6 \mathrm{j}-6 \mathrm{l}$ ). The medial region of the membranous compartment is larger in Potamorhina altamazonica (Fig. 5a and $5 \mathrm{~h}-5 \mathrm{j}$ ) than it is in Cyphocharax species, and Steindachnerina insculpta (Fig. 2a, $2 \mathrm{~h}$ and $2 \mathrm{j}-2 \mathrm{~m}$; Fig. $3 \mathrm{~g}$ and 3h; Fig. 4g and 4i; Fig. $6 \mathrm{a}$ and $6 \mathrm{j}-6 \mathrm{l})$.

In the spermatozoa of the Curimatidae, the medial and distal regions of the tail, or flagellum, lack the membranous compartment, showing only the classical 9+2 axoneme, and neither lateral fins nor intra-tubular differentiation is present
(Fig. 2a and 2k; Fig. 3g and 3h; Fig. 4j and 4k; Fig. 5a and 5h 5j; Fig. 6a, 6i and 6j).

\section{Discussion}

Among members of the Teleostei with external fertilization, the flagellum generally develops lateral to the nucleus in the early spermatid. The flagellar axis may be either perpendicular or parallel to the nucleus depending on whether or not nuclear rotation occurs (Mattei, 1970). The resulting spermatozoon, an aquasperm, has no acrosome, a head containing a spherical nucleus, a midpiece of variable dimensions with or without a cytoplasmic channel, and a long flagellum (Jamieson, 1991; Mattei, 1991). Nuclear rotation during spermiogenesis has been observed in all examined species of the Curimatidae, and apparently occurs in almost all other Characiformes whose spermatozoa have been described, with the exception of Acestrorhynchus falcatus (Matos et al., 2000) and Mimagoniates barberi (Pecio \& Rafinski, 1999). In spermatozoa of the Curimatidae, the nucleus is spherical (Matos et al., 1998; present paper) as in other species of Characiformes with external fertilization (Jamieson, 1991; Mattei, 1991; Quagio-Grassiotto et al., 2001). Some inseminating species of the Characiformes have a nucleus that moderately or substantially elongates backward or forward (Burns et al., 1998; Pecio \& Rafinski, 1999). On the other hand, Citharinus sp. (Citharinidae), a basal characiform species, has a conical nucleus (Mattei et al., 1995).
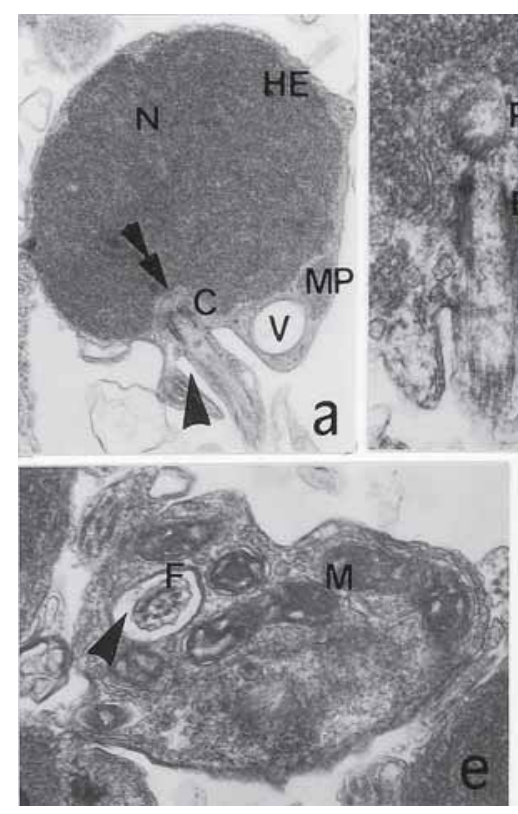
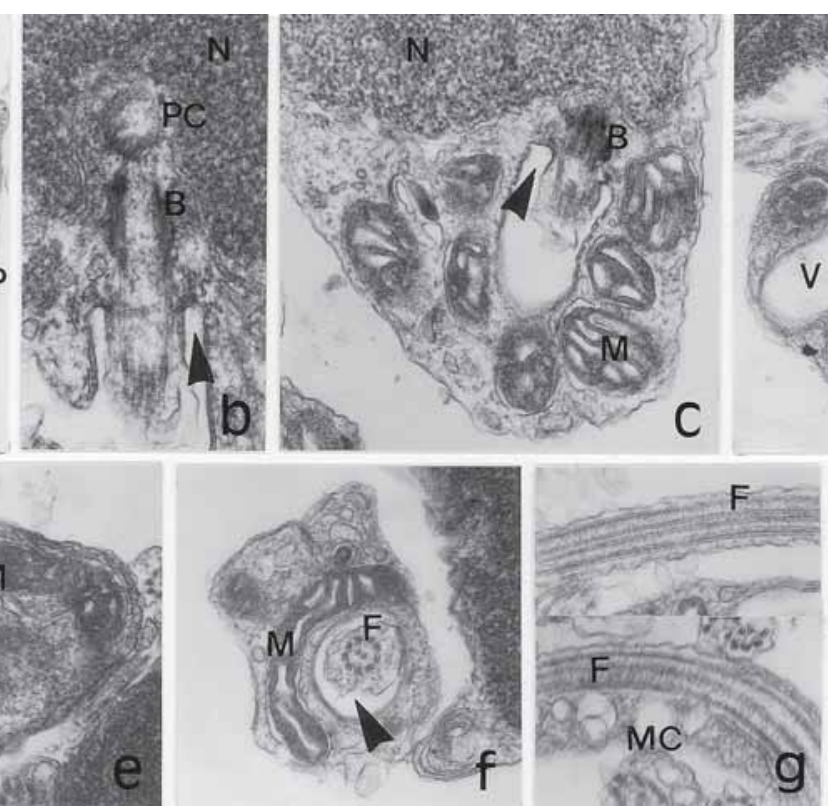
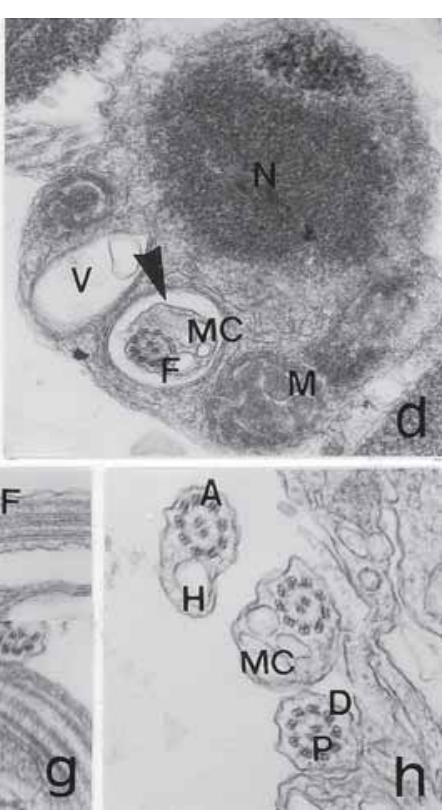

Fig. 3. Cyphocharax gillii spermatozoa. a: spermatozoon longitudinal section, X 13800; b: centriolar complex, X 34600; c- f: midpiece cross sections; c, X 22100; d, X 23000; e, X 23500; f, X 22000; g: flagella longitudinal sections, X 23000; h: flagella cross section, X 28900. A: axoneme; B: basal body; C: centriolar complex; D: peripheral microtubule doublets; F: flagellum; HE: head; M: mitochondrion; MC: membranous compartment; MP: midpiece; N: nucleus; P: single central pair of microtubules; PC: proximal centriole; V: vesicle; arrowhead: cytoplasmic channel; double arrowhead: nuclear fossa. 
In curimatid species, the nucleus of the spermatozoon displays thick fibers of highly condensed chromatin and some electron-lucent areas (Matos et al., 1998; present paper) similar to Hoplias malabaricus (Erythrinidae), where the electron lucent areas are few (Quagio-Grassiotto et al., 2001). In the nucleus of the spermatozoa of Citharinus sp. the chromatin forms highly condensed granules or clusters (Mattei et al., 1995). The chromatin may also be seen in clusters in some members of the family Characidae (Matos et al., 1993; Aires, 1998; Burns et al., 1998; Romagosa et al., 1999; Zaiden, 2000; Veríssimo-Silveira, 2003). Among other members of the Characiformes, spermatozoa generally exhibit thick fibers of homogeneously condensed chromatin (Jamieson, 1991; Mattei et al., 1995; Burns et al., 1998; Magalhães, 1998; Matos et al., 1998; Pecio \& Rafinski, 1999; Matos et al., 2000; Andrade et al., 2001; Quagio-Grassiotto et al., 2001).

The nuclear fossa is a shallow to deep depression located in the part of the nucleus that faces the midpiece. The nuclear fossa is considered to be of the moderate type if it has about one half of the nuclear diameter in length, and deep when it has more than one half of the nuclear diameter in length. A moderate-type of nuclear fossa is observed in the Curimatidae (Matos et al., 1995; present paper), Erythrinidae (QuagioGrassiotto et al., 2001) and within the Characidae in the subfamilies Aphyocharacinae (Burns et al., 1998) and Myleinae (Matos et al., 1993). A medial and shallow nuclear fossa, represented by a slight depression in the nuclear outline, is observed in spermatozoa of Citharinus sp., Citharinidae (Mattei et al., 1995). In some members of the Characidae (Bryconinae and Salmininae) the nuclear fossa is deep (Aires, 1998; Romagosa et al., 1999, Zaiden, 2000; Veríssimo-Silveira, 2003) while in others (Cheirodontinae) as well as in the family Acestrorhynchidae, the nuclear fossa is absent (Burns et al., 1998; Matos et al., 2000).

The flagellum usually develops lateral to the nucleus. This initial position may change during spermiogenesis depending on nuclear rotation. When the rotation of the nucleus is incomplete, the nuclear fossa is eccentric and so is the flagellum, which is perpendicular to the nucleus. If rotation is complete, the nuclear fossa is medial while the flagellum is medial and perpendicular to the nucleus. When the nucleus does not rotate, the nuclear fossa is lateral, and so is the flagellum, which is parallel to the nucleus. In all of these cases the nuclear fossa may also be absent. In spermatozoa of Citharinus sp., the flagellum occupies a medial position (Mattei et al., 1995). The same condition occurs within the Characidae in the inseminating species of the Cheirodontinae (Burns et al., 1998), Bryconinae (Aires, 1998; Romagosa et al., 1999; Zaiden, 2000) and Salmininae (Veríssimo-Silveira, 2003). An eccentric flagellum is a common feature in the Curimatidae (Matos et al., 1998; present paper), Erythrinidae (Quagio-Grassiotto et al., 2001), and in the characid subfamilies Aphyocharacinae (Burns et al., 1998), Cynopotaminae (Magalhães, 1998), and Tetragonopterinae (Andrade et al., 2001) including Hyphessobrycon innesi (Jamieson, 1991). In Acestrorhynchidae, the flagellum lies la- teral and parallel to the nucleus (Matos et al., 2000), and the same condition is observed in the inseminating species of the Glandulocaudinae (Burns et al., 1998).

The position of the centriolar complex is related to the shape of the nuclear fossa. When the nuclear fossa is deep, the centriolar complex is located inside it. If the nuclear fossa is of the moderate type, it may contain the entire centriolar complex or part of it, or only one of the centrioles while the other centriole lies outside the fossa. The nuclear fossa may still be shallow with one of the centrioles partially inside it while the other lies outside. If the nuclear fossa is absent, the centriolar complex usually lies close to the nucleus. In the Citharinidae the nuclear fossa is absent and the centriolar complex lies close to the nucleus (Mattei et al., 1995). On the other hand, in the Acestrorhynchidae the nuclear fossa is absent and the centriolar complex lies distant to the nucleus (Matos et al., 2000). In curimatid species (Matos et al., 2000; present paper) the centriolar complex is inside the moderatetype nuclear fossa. The same condition is observed in the characid subfamilies Bryconinae and Salmininae in which the centriolar complex is located inside the deep nuclear fossa (Aires, 1998; Romagosa et al., 1999, Zaiden, 2000; VeríssimoSilveira, 2003). In the Characidae, Hyphessobrycon innesi has a double-arched shallow nuclear fossa, with each centriole partially inside each arc (Jamieson, 1991). Apparently, the same occurs with the characid subfamily Glandulocaudinae (Burns et al., 1998; Pecio \& Rafinski, 1999). In the Erythrinidae, Hoplias malabaricus has a nuclear fossa of the moderate type and only the proximal centriole is located inside the fossa (Quagio-Grassiotto et al., 2001).

In many cypriniform species (Baccetti et al., 1984) the arrangement of the centrioles is variable and considered species-specific (Mansour et al., 2002). The proximal centriole may be anterior or lateral to the distal centriole. In either case, it may be coaxial, parallel, oblique or perpendicular to the distal centriole. In Citharinus sp. the proximal centriole is lateral, oblique and distant from the distal centriole (Mattei et al., 1995). Among species of the Curimatidae, the proximal centriole is anterior, medial to slightly lateral, and at a right or slightly oblique angle relative to the distal centriole. In the Erythrinidae, the proximal centriole is anterior, coaxial and slightly oblique to the basal body (Quagio-Grassiotto et al., 2001). In the Acestrorhynchidae, the proximal centriole is anterior, lateral and perpendicular to the basal body (Matos et al., 2000). In the characid Hyphessobrycon innesi, it is antero-lateral and slightly oblique to the basal body (Jamieson, 1991). In Bryconinae, it is anterior, medial and perpendicular to the basal body (Aires, 1998; Romagosa et al., 1999; Zaiden, 2000). In all Glandulocaudinae species (Burns et al., 1998; Pecio \& Rafinski; 1999), the centriolar complex apparently repeats the arrangement observed in the Bryconinae, in which the proximal centriole is anterior, medial, and perpendicular to the basal body.

The midpiece is located at the posterior end of the nucleus in most members of the Teleostei (Jamieson, 1991; Mattei, 1991). In the species of the Curimatidae analyzed (Matos et 


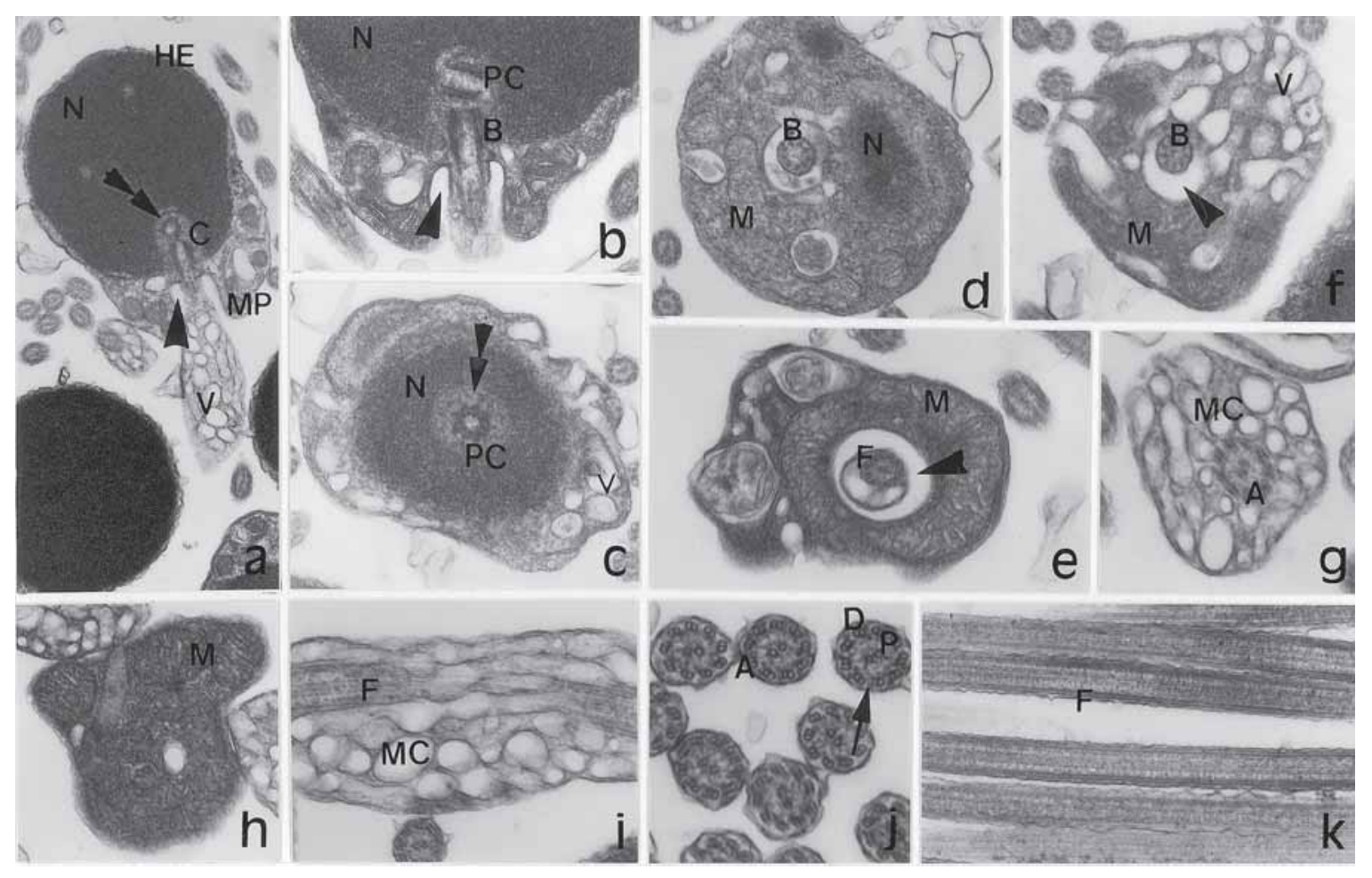

Fig. 4. Cyphocharax spilotus spermatozoa. a: spermatozoon longitudinal section, X 11900; b: midpiece longitudinal section, X 18500; c - f: midpiece cross sections; $\mathbf{c}$ and d, X17000; e, X 23000; f, X 17200; $\mathbf{g}$ and j: flagella cross-sections; g, X 34000; j, X 4200; h: mitochondrion, X 22000; i and k: flagella longitudinal sections; i, X 31500; k, X 23000. A: axoneme; B: basal body; C: centriolar complex; D: peripheral microtubule doublets; F: flagellum; HE: head; M: mitochondria; MC: membranous compartment; MP: midpiece; N: nucleus; P: single central pair of microtubules; PC: proximal centriole; V: vesicle; arrow: dinein arm; arrowhead: cytoplasmic channel; double arrowhead: nuclear fossa.

al., 1995; present paper), as in other members of the Characiformes (Jamieson, 1991; Matos et al., 1993; 1998; Mattei et al., 1995; Burns et al, 1998; Quagio-Grassiotto et al., 2001 Andrade et al., 2001) the midpiece is located at the posterior end of the nucleus. However, in the Acestrorhynchidae (Matos et al., 2000) and the characid species of the Glandulocaudinae (Burns et al., 1998; Pecio \& Rafinski, 1999) the midpiece is lateral to the nucleus.

In the Teleostei, the midpiece is usually short and contains a reduced cytoplasmic channel. In some cases, however, it may be long and have a long cytoplasmic channel (Jamieson, 1991; Mattei, 1991). Furthermore, the midpiece may or may not exhibit a cytoplasmic sheath. When the midpiece is long, the cytoplasm and mitochondria are accumulated in the anterior one third, whereas the posterior part consists of a cytoplasmic sheath or collar that generally has a dilated posterior region. The cytoplasmic sheath is formed by as a thin cytoplasmic projection that envelops the cytoplasmic channel (Jamieson, 1991; Mattei, 1991). The cytoplasmic channel is formed during spermiogenesis by movement of the centriolar complex towards the nucleus, taking with it the plasma membrane and initial segment of the flagellum (Mattei, 1970). In the Citharinidae (Mattei et al., 1995) and Erythrinidae
(Quagio-Grassiotto et al., 2001) the midpiece is short and the cytoplasmic channel is absent. In Erythrinidae the cytoplasmic channel formed during spermiogenesis does not remain in the mature spermatozoa (Quagio-Grassiotto et al., 2001).

A short midpiece and short cytoplasmic channel were observed in the Curimatidae (Matos et al., 1998; present paper), Acestrorhynchidae (Matos et al., 2000), and the subfamilies Cynopotaminae (Magalhães, 1998) and Tetragonopterinae (Andrade et al., 2001) of the Characidae. In the characid species Hyphessobrycon innesi of the Tetragonopterinae (Jamieson, 1991) and the subfamilies Bryconinae (Aires, 1998; Romagosa et al., 1999; Zaiden, 2000), Myleinae (Matos et al., 1993), and Salmininae (Veríssimo-Silveira, 2003), the posterior two thirds of the long midpiece consists of a cytoplasmic sheath or collar with dilated ends, encompassing a long cytoplasmic channel. In general, species of the Glandulocaudinae have a long midpiece and long cytoplasmic sheath attached to one side of the nucleus (Burns et al., 1998). Exceptions are the species of Mimagoniates (Burns et al., 1998: Pecio \& Rafinski, 1999) that have a short cytoplasmic sheath. A long midpiece with no cytoplasmic sheath is also found in the inseminating cheirodontine Macropsobrycon uruguayanae (Burns et al., 1998). 

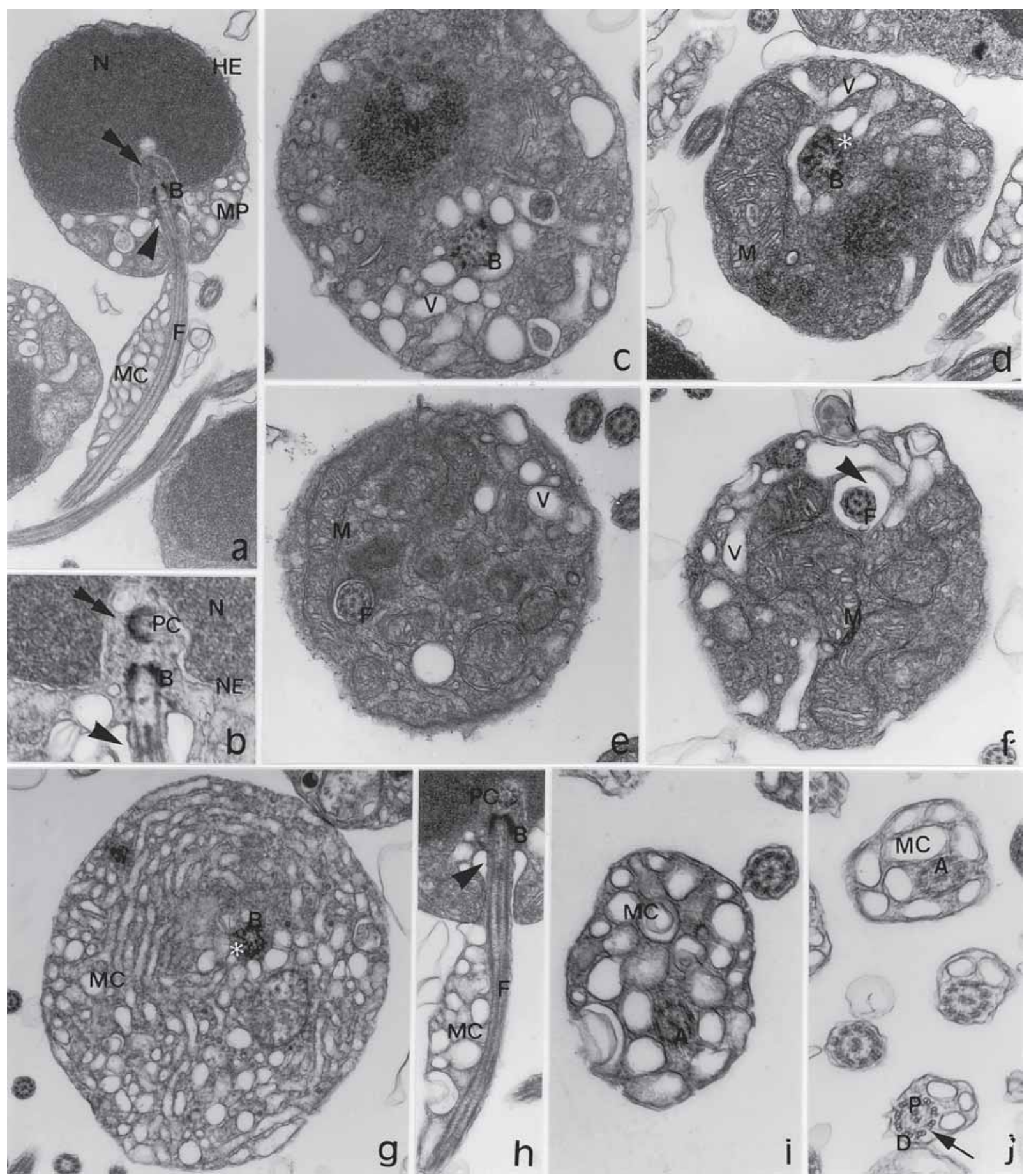

Fig. 5. Potamorhina altamazonica spermatozoa. a: spermatozoon longitudinal section, $X$ 13600; b: centriolar complex, $X$ 25500; $\mathbf{c}$ - g: midpiece cross sections; $\mathbf{c}$ and d, X 23000; $\mathbf{e}$ and f, X 25200; g, X 15900; h: midpiece and flagellum longitudinal section, X 17500; i and j: flagella cross-sections; i, X 42000; j, X 37800. A: axoneme; B: basal body; C: centriolar complex; D: peripheral microtubule doublets; F: flagellum; HE: head; M: mitochondria; MC: membranous compartment; MP: midpiece; N: nucleus; NE: nuclear envelop; P: single central pair of microtubules; PC: proximal centriole; V: vesicle; asterisks: anchorage fibrils; arrow: dinein arm; arrowhead: cytoplasmic channel; double arrowhead: nuclear fossa.

Vesicles, which are usually found in the midpiece of spermatozoa of Characiformes, may be few in number and dispersed or form a well-developed and organized system. A midpiece containing many regularly arranged tubules was described in the Citharinidae (Mattei et al., 1995). A different arrangement, i.e. the presence of many anteroposteriorlyelongate vesicles interspersed by narrow strips of cytoplasm, was observed in the Erythrinidae (Quagio-Grassiotto et al., 


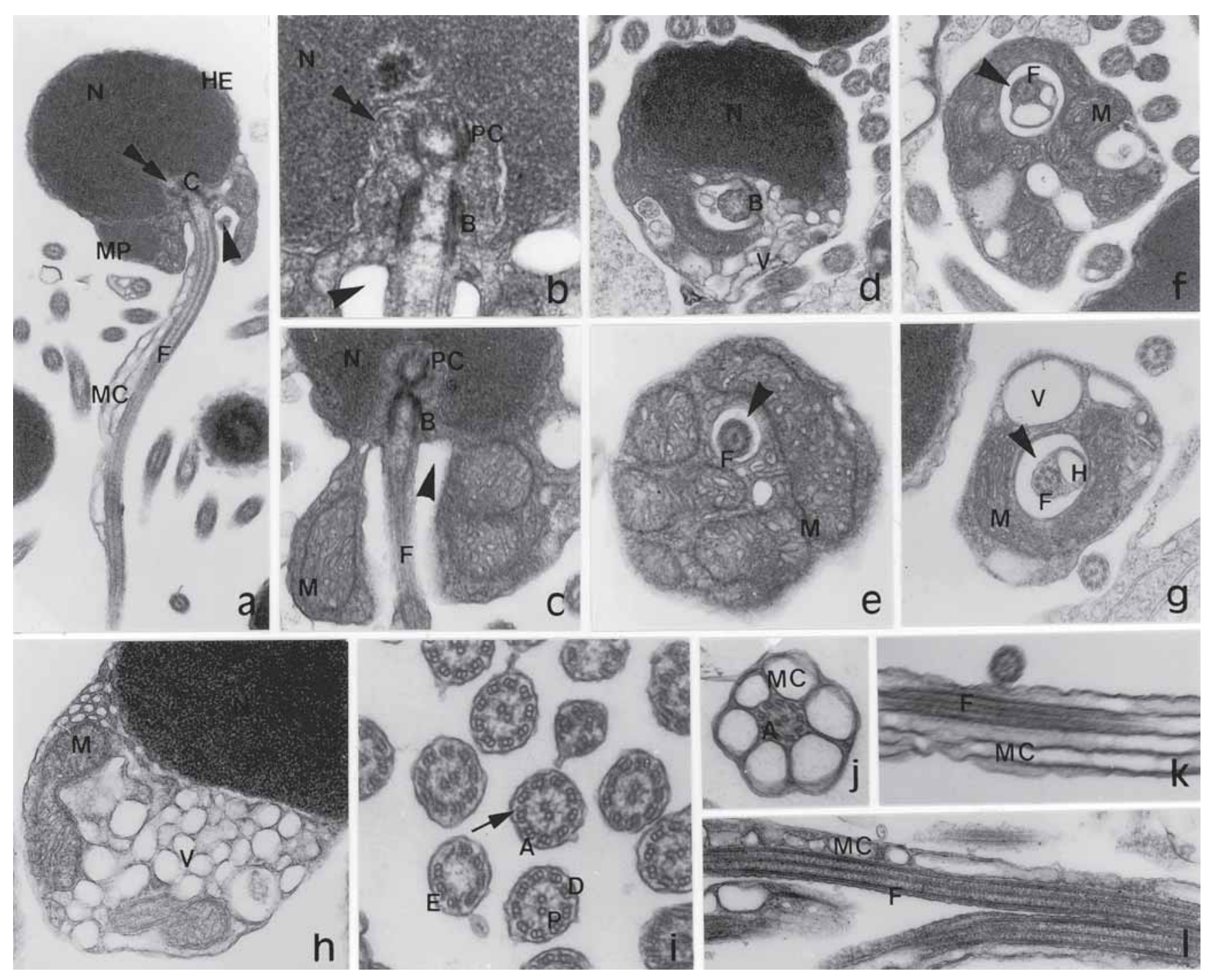

Fig. 6. Steindachnerina insculpta spermatozoa. a: spermatozoon longitudinal section, X 13600; b: centriolar complex, X 46200; c and h: midpiece longitudinal sections; c, X 22100; h, X 23800; d - g: midpiece cross sections; d, X 22000; e, X 27600; f, X 25200; g, X 23000; $\mathbf{i}$ and $\mathbf{j}$ : flagella cross sections; $\mathbf{i}$, X 53300; j, X 37800; $\mathbf{k}$ and $\mathbf{l}$ : flagella longitudinal sections, X 23000. A: axoneme; B: basal body; C: centriolar complex; D: peripheral microtubular doublets; E: axoneme end; F: flagellum; H: membranous hoops; HE: head; M: mitochondria; MC: membranous compartment; MP: midpiece; N: nucleus; P: single central pair of microtubules; PC: proximal centriole; V: vesicle; arrow: dinein arm; arrowhead: cytoplasmic channel; double arrowhead: nuclear fossa.

2001). In species of the Curimatidae, the midpiece has several elongate, dispersed vesicles or cisternae connected to the plasma membrane (Matos et al., 1995; present paper), as it does in the characid subfamilies Aphyocharacinae (Burns et al., 1998), Cynopotaminae (Magalhães, 1998), Tetragonopterinae (Andrade et al., 2001), and in an inseminating species of the Cheirodontinae (Burns et al., 1998). In the long midpiece of Bryconinae (Aires, 1998; Romagosa et al., 1999; Zaiden, 2000), Myleinae (Matos et al., 1993), Salmininae (VeríssimoSilveira, 2003), Hyphessobrycon innesi of the Tetragonopterinae (Jamieson, 1991), and Acestrorhynchidae (Matos et al., 2000) there are few sparse vesicles.

In the spermatozoa of the Otophysi, there are usually only a few, small, round or elongate mitochondria, grouped in the anterior one-third of the cytoplasmic collar around the centriolar complex and at the initial region of the axoneme, which is separated from the cytoplasmic collar by the cytoplasmic channel (Jamieson, 1991; Mattei 1988, 1991). In the Citharinidae there are a few, long mitochondria located close to the nucleus near the centriolar complex (Mattei et al., 1995). In the species of the Curimatidae (Matos et al., 1995; present paper) as in the Eythrinidae (Quagio-Grassiotto et al., 2001), there are only one to three mitochondria that appear to be elongate, and may be ramified or $\mathrm{C}$-shaped.

In the species of the Curimatidae, mitochondria are grouped around the initial region of the axoneme and separated from it by the cytoplasmic channel (Matos et al., 1995; present paper). In the Erythrinidae, due to the fact that 
a cytoplasmic channel is absent, mitochondria are grouped directly around the initial region of the axoneme (QuagioGrassiotto et al., 2001). Among characid subfamilies that have a short midpiece, mitochondria are located close to the nucleus near the centriolar complex. On the other hand, in the members of the Characidae that have a long midpiece, such as Myleinae (Matos et al., 1993), Bryconinae (Aires, 1998; Romagosa et al., 1999; Zaiden, 2000), Salmininae (Veríssimo-Silveira, 2003) and Hyphessobrycon innesi (Jamieson, 1991), the mitochondria are grouped in the anterior third of the midpiece around the initial region of the axoneme and are separated from the axoneme by the cytoplasmic channel. The same arrangement is observed in an inseminating species of the Cheirodontinae (Burns et al., 1998). In species of the Glandulocaudinae, the elongate mitochondria are grouped and located close to the posterior end of the nucleus (Burns et al., 1998; Pecio \& Rafinski, 1999). The Acestrorhynchidae have few elongate mitochondria located around the nucleus and around the initial region of the axoneme, separated from the axoneme by the cytoplasmic channel (Matos et al., 2000).

In most of the Otophysi, spermatozoa have only one flagellum comprising a classical axoneme with two central microtubules and nine peripherical doublets surrounded by the plasma membrane (Jamieson, 1991; Mattei 1988, 1991). Among teleosts, the flagella may have intratubular differentiations and lateral expansions of variable length, referred to as fins. To date, the occurrence of flagellar lateral fins or intratubular differentiations has not been described in the spermatozoa of any characiform species, including the species of the Curimatidae in the present study (Jamieson, 1991; Matos et al., 1993, 1998; Mattei et al., 1995; Burns et al., 1998; Aires, 1998; Magalhães, 1998; Pecio \& Rafinski 1999; Romagosa et al., 1999; Zaiden, 2000; Andrade et al., 2001; Quagio-Grassiotto et al., 2001).

The membranous compartment found in the initial region of the flagellum of the species of Curimatidae analyzed in the present study has so far not been described in any other characiforms species, although the "lattice tubule" described for Citharinus sp. may be similar (Mattei et al., 1995). A similar structure was described in nine cypriniform species in five subfamilies of the Cyprinidae (Baccetti et al., 1984; Kim et al., 1998; Lee \& Kim, 1998), but this seems to be homoplastic. Even though this character has so far been reported only in Curimatidae within the Characiformes, further information on the spermatozoal structure of other characiforms is prerequisite to better understanding the phylogenetic significance of the membranous compartment in the initial region of the flagellum. This is particularly the case in taxa considered to be closely related to Curimatidae (Prochilodontidae and the Clade Anostomidae + Chilodontidae).

The general characteristics of the spermatozoa found in the six species of Curimatidae that belong to four different genera were very similar, particularly in the species of the same genus (Matos et al., 1995; present paper). This agrees with the hypothesis of the monophyly of the Curimatidae (Vari, 1983; 1989) and supports the hypothesis of Baccetti et al. (1984), that species of the same family should have the same distribution of organelles within the spermatozoon. Several characters that are found in Curimatidae and observed in other characiform spermatozoa may be synapomorphies for some families and thus useful in the phylogenetic analysis of the order. Examples include: the membranous compartment found in the anterior flagellar region of curimatid species (Matos et al., 1995; present paper), the midpiece with many elongate vesicles and the absence of a cytoplasmic channel in the Erythrinidae (Quagio-Grassiotto et al., 2001), and the lateral flagella with nine dense fibers around the initial region of the axoneme in the Acestrorhynchidae (Matos et al., 2000). To date, only incomplete information about the modification of the spermatozoa of only five (Characidae, Curimatidae, Erythrinidae, Acestrorhynchidae and Citharinidae) of the 20 characiform families recognized by Buckup (1998) is available. This lack of data prevents a better understanding of the significance of all the ultrastructural characteristics of curimatid spermatozoa.

\section{Acknowledgments}

We acknowledge John Burns and Richard Vari for their critical review of the manuscript. We thank Edmir D. Carvalho and Francisca Estela Lima Freitas for help during the collection of specimens and the E. M. Laboratory/IBB-UNESP for access to that facility. This research was supported by the Brazilian Agencies: CAUNESP (Centro de Aqüicultura da Universidade Estadual Paulista); FAPESP (Fundação de Apoio à Pesquisa do Estado de São Paulo); and CNPq (Conselho Nacional de Desenvolvimento Científico e Tecnológico).

\section{Literature Cited}

Aires, E. D. 1998. Características morfológicas e histofisiológicas da via espermática da Piracanjuba, Brycon orbignyanus (Pisces, Teleostei). Unpublished Ph.D. Dissertation, Universidade Estadual Paulista, Botucatu.

Andrade R. F., N. Bazzoli, E. Rizzo \& Y. Sato. 2001. Continuous gametogenesis in the neotropical freshwater teleost, Bryconops affinis (Pisces: Characidae). Tissue \& Cell, 33: 524-532.

Baccetti, B., A. G. Burrini, G. Callaini, G. Gilbertini, M. Mazzini \& S. Zerunian. 1984. Fish germinal cells. I. Comparative spermatology of seven cyprinid species. Gamete Research, 10:373-396.

Buckup, P. A. 1998. Relationship of the Characidiinae and Phylogeny on Characiform Fishes (Teleostei: Ostariophysi). Pp.123-144. in: Malabarba, L. R., R. E. Reis, R. P. Vari, Z. M. S. Lucena \& C. A. S. Lucena (Eds.). Phylogeny and Classification of Neotropical Fishes. Porto Alegre, Edipucrs, 603p.

Burns, J. R., S. H. Weitzman, K. R. Lange \& L. R. Malabarba. 1998. Sperm ultrastructure in characid fishes (Teleostei, Ostariophysi). Pp.235-244. in: Malabarba, L. R., R. E. Reis, R. P. Vari, Z. M. S. Lucena \& C. A. S. Lucena (Eds.). Phylogeny and Classification of Neotropical Fishes. Porto Alegre. Edipucrs, 603p. 
Jamieson, B. G. M. 1991. Fish Evolution and Systematics: Evidence from Spermatozoa. Cambridge: Cambridge University Press, 319p.

Kim, K. H., A. S. Kwon \& Y. H. Lee. 1998. Spermatozoal ultrastructure and phylogenetic relationship of the subfamily Gobioninae (Cyprinidae) 2. Ultrastructure of spermatozoa in the Korean gudgean, Squalidus chankaensis tsuchigae. Korean Journal of Limnology, 31: 159-164.

Lee, Y. H. \& K. H. Kim. 1998. Ultrastructure of spermatozoa in Pungtungia herzi. Development and Reproduction, 2: 141-148.

Magalhães, A. L. B. de 1998. Gametogênesis e reprodução de Galeocharax knerii (Steindachner, 1879) (Pisces, Characidae) nos reservatórios de Furnas e Itumbiara: estudo biométrico, histológico e ultra-estrutural. Unpublished M. Sc. Dissertation, Universidade Federal de Minas Gerais, Belo Horizonte.

Mansour N., F. Lahnsteiner \& C. A. Patzner. 2002. The spermatozoon of the African catfish: fine structure, mobility, viability and behavior in seminal vesicle secretion. Journal of Fish Biology, 60: 545-560.

Matos, E., P. Matos, L. Corral \& C. Azevedo. 2000. Estrutura fina do espermatozóide de Acestrorhyncus falcatus Bloch (Teleostei, Characidae) da região norte do Brasil. Revista Brasileira de Zoologia, 17: 747-752.

Matos, E., P. Matos, E. Oliveira \& C. Azevedo. 1993. Ultraestrutura do espermatozóide do pacu, Metynnis maculatus Kner, 1860 (Pisces, Teleostei) do rio Amazonas. Revista Brasileira de Ciências Morfológicas, 10: 7-10.

Matos, E., P. Matos, M. N. S. Santos \& C. Azevedo. 1998. Aspectos morfológicos e ultraestruturais do espermatozóide de Curimata inornata Vari, 1989 (Pisces, Teleostei) do rio Amazonas. Acta Amazônica, 28: 449-453.

Mattei, X. 1970. Spermiogenése comparé des poisson. Pp.5772. in: Baccetti, B. (Ed.). Comparative Spermatology. New York: Academic Press, 773p.

Mattei, X. 1988. The flagellar apparatus of spermatozoa in fish. Ultrastructure and evolution. Biology of the Cell, 63: 151-158.

Mattei, X. 1991. Spermatozoon ultrastructure and its systematic implications in fishes. Canadian Journal of Zoology, 69: 3038-3055.

Mattei, X., B. Marchand \& O. T. Thiaw. 1995. Unusual midpiece in the spermatozoon of the teleost fish, Citharinus sp.
Journal of Submicroscopy, Cytology, and Pathology, 27: 189-191.

Pecio, A. \& J. Rafinski. 1999. Spermiogenesis in Mimagoniates barberi (Teleostei, Ostariophysi, Characidae), an oviparous, internally fertilizing fish. Acta Zoológica, 80: $35-45$.

Quagio-Grassiotto, I. \& E. D. Carvalho. 2000. Ultrastructure of Sorubim lima (Teleostei, Siluriformes, Pimelodidae) spermiogenesis. Journal of Submicroscopy, Cytology, and Pathology, 32: 654-659.

Quagio-Grassiotto, I., J. N. C. Negrão, E. D. Carvalho \& F. Foresti. 2001. Ultrastructure of spermiogenic cells and spermatozoa in Hoplias malabaricus (Teleostei, Characiformes, Erythrinidae). Journal of Fish Biology, 59: 1948-1502.

Romagosa, E., M. Y. Narahara, M. I. Borella, S. F. Parreira \& N. Fenerich-Verani. 1999. Ultrastructure of the germ cells in the testis of matrinxã, B. orbignyanus (Teleostei, Characidae). Tissue Cell, 31: 540-544.

Vari, R. P. 1983. Phylogenetic relationships of the families Curimatidae, Prochilodontidae, Anostomidae and Chilodontidae (Pisces: Characiformes). Smithsonian Contributions to Zoology 378: 1- 60.

Vari, R. P. 1989. A phylogenetic study of the Neotropical characiform family Curimatidae (Pisces: Ostariophysi). Smithsonian Contributions to Zoology, 471: 1- 71.

Vari, R. P. 1998. Higher level phylogenetic concepts within Characiforms (Ostariophysi), a historical review. Pp.111122. in: Malabarba, L. R., R. E. Reis, R. P. Vari, Z. M. S. Lucena \& C. A. S. Lucena (Eds.). Phylogeny and Classification of Neotropical Fishes. Porto Alegre, Edipucrs, 603p.

Veríssimo-Silveira, R. 2003. Ciclo reprodutivo e cinética da espermatogênese do dourado (Salminus maxillosus, 1849). Unpublished M. Sc. Dissertation, Universidade Estadual Paulista, Jaboticabal. 60p.

Zaiden, S. F. 2000. Morfologia gonadal e metabolismo energético da piraputanga Brycon hilarii (Cuvier e Valenciennes) (Pisces, Characidae) em cativeiro, durante o ciclo reprodutivo anual. Unpublished Ph.D. Dissertation, Universidade Estadual Paulista, Jaboticabal. $152 \mathrm{p}$.
Received June 11, 2003 Accepted August 25, 2003 